\title{
Teh Herbal Antibakteri dari Ekstrak Tumbuhan Patikan Cina, (Euphorbia thymifolia Linn.)
}

\section{Antibacterial Herbal Tea of Patikan Cina Extract Plant, (Euphorbia thymifolia Linn.)}

\author{
Afrida $^{1^{*}}$, Aulia Sanova ${ }^{1}$ \\ ${ }^{1}$ Pendidikan Matematika dan Ilmu Pengetahuan Alam, Fakultas Keguruan dan Ilmu Pendidikan Universitas Jambi, \\ Indonesia
}

\begin{abstract}
A B S T R A K
Tumbuhan patikan cina (Euphorbia thymifolia Linn.) sudah sejak lama dimanfaatkan oleh masyarakat di pedesaan secara tradisional sebagai obat dan telah terbukti memiliki khasiat untuk pengobatan berbagai jenis penyakit, diantaranya diare dan disentri. Penelitian ini bertujuan untuk mengembangkan teh herbal Patikan Cina yang berkhasiat sebagai antibakteri terhadap Escherichia coli dan Shigella dysenteriae sebagai minuman fungsional untuk pengobatan penyakit diare dan disentri. Pembuatan teh herbal patikan cina dilakukan dengan mencampur filtrat patikan cina dan daun stevia (70:30, 80:20, 90:10 $\mathrm{v} / \mathrm{v})$ kemudian ditambahkan filtrat daun jambu biji $(0 \%, 2,5 \%, 5 \%$, dan 7,5\%). Kemudian diaduk hingga homogen. Sehingga diperoleh 12 formula minuman teh herbal patikan cina. Metode penelitian dilakukan menggunakan Rancangan Acak Lengkap (RAL) dan tiap perlakuan diulang sebanyak 3 kali. Penentuan teh herbal terbaik dipilih dengan pembobotan secara subyektif. Teh herbal terbaik yang terpilih dari campuran patikan cina, daun stevia, dan daun jambu biji adalah teh herbal dengan komposisi formulasi patikan cina $70 \%$; stevia 30\%; tanpa penambahan daun jambu biji. Produk teh herbal terbaik yang terpilih memiliki pH 5,02; kadar sari 0,5\%; serta mampu menghambat E.coli 0,15 mm dan S.dysentriae 8,22 mm.
\end{abstract}

\section{A B S TRACT}

Patikan Cina plant (Euphorbia thymifolia Linn.) have long been traditionally used by rural communities as medicine and have been shown to have properties for the treatment of various types of diseases, including diarrhea and dysentery. This study aims to develop Patikan Cina herbal tea which has the ability to be antibacterial against Escherichia coli and Shigella dysenteriae as a functional beverage for the treatment of diarrheal diseases and dysentery. Patikan Cina herbal tea done by mixing Patikan Cina extract and stevia leaf filtrate $(70: 30,80: 20,90: 10 \mathrm{v} / \mathrm{v})$ then adding guava leaf fitrate $(0 \%, 2,5 \%, 5 \%$, dan 7,5\%). Then stir until homogeneous. In order to obtain 12 Patikan Cina herbal tea beverage formulas. The research method was conducted using a completely randomized design and each treatment was repeated 3 times. Determination of the best herbal tea is selected by weighting subjectively. The best herbal tea selected from a mixture of Patikan Cina, stevia leaf, and guava leaf is herbal tea with formulation composition $70 \%$ Patikan Cina, 30\% stevia leaf, without the addition of guava leaf. The best selected herbal tea product has pH of 5.02; extract content of 0.5\%; and able to inhibit E.coli 0,15 mm and S.dysentriae 8,22 $\mathrm{mm}$.

Kata kunci : Anti bakterial; Euphorbia thymifolia Linn, teh herbal. Keyword : anti-bacterial; Euphorbia thymifolia Linn; herbal tea.

I N F O A R T I K E L

Received: 05 Feb 2020;

Revised: 24 Apr 2020;

Accepted: 14 May 2020

* coresponding author: risetida73@gmail.com

DOI: https://doi.org/10.22437/jisic.v12i1.8689 


\section{PENDAHULUAN}

Tumbuhan patikan cina (Euphorbia thymifolia L.) merupakan tumbuhan terna liar yang hidup merayap di padang rumput halaman atau tegalan. Tumbuhan ini masih asing di telinga masyarakat kita sehingga kurang dimanfaatkan bahkan sering dianggap gulma. Di India, tumbuhan ini sudah popular sejak dahulu dan masuk dalam pengobatan tradisional India (Ayurverda). Menurut Utami (2008), tumbuhan patikan cina dipercaya dapat mengobati radang tenggorokan, bronkitis, asma, disentri, radang perut, diare, kencing darah, radang kelenjar usus, payudara bengkak, dan eksim). Dari uji fitokimia yang telah dilakukan pada penelitian sebelumnya menunjukkan bahwa patikan cina mengandung senyawa alkaloid, flavonoid, steroid, terpenoid, dan fenolik (Afrida, Jhon, Dwilistian, \& Nengsih, 2014). Baslas \& Agarwal (1980) telah berhasil mengisolasi berbagai senyawa turunan fenol dari seluruh bagian tumbuhan ekstrak petroleum eter dan ekstrak etanol. Tumbuhan ini juga dapat menghambat pertumbuhan bakteri gram positif (Bacillus subtils) dan gram negatif (E.coli) dalam pelarut $\mathrm{HCl} 1,5 \%$. Sushma \& Randhir (2016) berhasil mengisolasi senyawa isomer Flavan-3-ol berupa senyawa catechin dan epicatechin. Kedua senyawa tersebut merupakan turunan flavonoid, yang memiliki peranan dalam menghambat aktivitas anti-bactery, antifungal dan insektisida (Geissman, 1962 dalam Dwilistiani, 2013). Diversifikasi minuman teh herbal patikan cina ini diharapkan mampu meningkatkan nilai gizi dan aktivitas senyawa didalamnya. Selain berkhasiat dalam menjaga kesehatan tubuh manusia juga memiliki nilai tambah dalam segi cita rasa dengan penambahan pemanis alami daun stevia dan daun jambu biji sebagai tambahan dalam meningkatkan efek antibakterinya terhadap bakteri patogen penyebab diare.

Penelitian ini merupakan lanjutan dari kajian aktivitas antibakteri dalam teh herbal Patikan Cina, untuk menggali potensi tumbuhan ini sebagai minuman fungsional yang dapat digunakan sebagai obat herbal untuk penyakit diare dan disentri terhadap bakteri Escherichia coli dan Shigella dysenteriae.

\section{METODE PENELITIAN}

\section{Bahan}

Bahan yang digunakan untuk pembuatan teh herbal adalah patikan cina, daun stevia dan daun jambu biji serta akuades sebagai pelarutnya. Tumbuhan Patikan Cina (Euphorbia thymifolia Linn) dikumpulkan dari kawasan sekitar kota Jambi. Identifikasi tumbuhan dilakukan di Lab. Bioteknologi dan Rekayasa Fakultas Sains dan Teknologi Universitas Jambi. Bahan yang digunakan untuk analisis adalah Reagen uji fitokimia, $\mathrm{FeCl}_{3}, \mathrm{NaOH}$, $\mathrm{K}_{3} \mathrm{Fe}(\mathrm{CN})_{6}$, serbuk $\mathrm{Mg}, \mathrm{HCl}$, dan Nutrien Agar. Bakteri uji yang digunakan dalam penelitian ini adalah : Escherichia coli dan Shigella dysenteriae. Bakteri uji yang digunakan diperoleh dari Laboratorium Politeknik Kesehatan Bandung dan Laboratorium Mikrobiologi Universitas Jambi.

\begin{abstract}
Alat
Alat yang digunakan pada pembuatan teh herbal patikan cina adalah gelas ukur, timbangan analitik, panci, sendok, refrigerator, pisau, baskom, cup plastik, kertas saring dan kompor listrik. Alat yang digunakan untuk analisis adalah tabung reaksi, spektrofotometer, oven, desikator, cawan porselin, autoclave, tanur, aluminium foil, pipet ukur, pipet mikro, petri disk, dan kertas cakram.
\end{abstract}

\section{Analisis Bahan Baku}

Teh herbal Patikan Cina terdiri dari tumbuhan Patikan Cina, daun stevia dan daun jambu biji yang dibuat dalam bentuk filtrat. Pengujian yang dilakukan pada bahan baku minuman teh herbal ini meliputi analisis fitokimia, kadar air, kadar abu, kadar tanin, dan aktivitas antibakteri. 


\section{Formulasi Minuman Teh Herbal}

Teh herbal yang akan dibuat adalah teh herbal Patikan Cina (Euphorbia thymifolia Linn.). Bahan yang digunakan untuk formulasi teh herbal adalah bagian tumbuhan Patikan Cina (Euphorbia thymifolia Linn.) dan herbal lain (daun stevia dan daun jambu biji) sebagai aditif untuk memberi rasa, warna dan memberi aroma. Pembuatan filtrat teh herbal Patikan Cina dilakukan dengan metode ekstraksi (suhu air $100^{\circ} \mathrm{C}$, suhu filtrat $90^{\circ} \mathrm{C}$ selama 15 menit, dengan perbandingan $1: 10$. Demikian juga pembuatan filtrat daun stevia dan filtrat daun jambu biji.

Pembuatan teh herbal Patikan Cina dilakukan dengan mencampur filtrat Patikan Cina dan daun stevia (70:30, 80:20, 90:10 v/v) kemudian ditambahkan filtrat daun jambu biji $(0 \%, 2,5 \%, 5 \%$, dan $7,5 \%)$.Kemudian diaduk hingga homogen. Sehingga diperoleh sejumlah formula minuman teh herbal Patikan Cina. Dalam pengujian disertakan satu formula sebagai teh kontrol. Teh kontrol yang disertakan berupa teh hijau sebanyak 1 gram. Air yang digunakan untuk membuat seduhan adalah sebanyak $100 \mathrm{ml}$.

\section{Analisis Produk}

Analisis yang dilakukan pada formulasi produk meliputi analisis aktifitas antibakteri terhadap E.coli dan $S$. dysentriae, $\mathrm{pH}$, kadar sari, serta pengujian organoleptik terhadap aroma, warna dan rasa.

\section{Analisis Data}

Analisa ragam dilakukan untuk mengetahui adanya pengaruh perbedaan formulasi teh terhadap kadar sari, nilai $\mathrm{pH}$, aktivitas antibakteri, dan nilai hedonik (uji Organoleptik) dari teh herbal patikan cina yang dihasilkan. Analisa data dilakukan secara ANOVA dengan selang kepercayaan 95\%. Apabila ditemukan pengaruh terhadap salah satu variabel maka dilanjutkan uji lanjutan dengan uji Duncan yang tingkat signifikasinya 0,05. Analisa organoleptik dengan menggunakan uji Friedman.

\section{HASIL DAN PEMBAHASAN}

\section{Uji aktifitas antibakteri bahan baku teh herbal}

Uji aktivitas antibakteri E.coli dan S.dysentriae pada bahan baku (Patikan cina, daun Stevia, daun jambu biji) dilakukan dengan menggunakan metode difusi cakram. Kontrol positif yang digunakan yaitu Amoxicillin 10\% dan kontrol negatif yang digunakan yaitu akuades. Pada setiap cakram ditetesi bahan baku yang sudah dilarutkan dengan akuades lalu diletakkan pada cawan petri yang telah diinokulasi $E$. coli dan $S$. dysentriae kemudian diinkubasi selama 24 jam. Luas daerah zona hambat diketahui dengan cara mengukur diameter zona hambat yang terbentuk di sekitar cakram dengan jangka sorong, kemudian rata-rata zona hambat tiap cakram dibandingkan dengan rata-rata zona hambat pada cakram yang lain. Hasil pengukuran rata-rata diameter zona hambat dapat dilihat pada tabel 1 .

Tabel 1. Zona hambat bahan baku pada bakteri E.coli dan S.dysentriae

\begin{tabular}{llccccc}
\hline \multirow{2}{*}{ Bakteri } & Nama Sampel & \multicolumn{3}{c}{ Zona Hambat (mm) } & Rata-rata & $\begin{array}{c}\text { Kontrol Positif } \\
(\mathbf{m m})\end{array}$ \\
\cline { 3 - 5 } E. coli & Patikan cina & 0,08 & 0,12 & 0,16 & 0,12 & 4,69 \\
& Daun Stevia & 0,16 & 0,16 & 0,08 & 0,07 & \\
& Daun jambu biji & 0,072 & 0,02 & 0,18 & 0,09 & 4,73 \\
\hline Shigella & Patikan cina & 6,4 & 12,01 & 12,49 & 10,30 & \\
dysentriae & Daun Stevia & 0,56 & 2,14 & 1 & 1,23 & \\
& Daun jambu biji & 10,45 & 9,96 & 10,46 & 10,29 & \\
\hline
\end{tabular}

Pada tabel 1. menunjukkan bahwa pada uji bakteri E.coli terbentuk zona hambat meskipun relatif kecil. Diperkirakan zona hambat yang terbentuk 
merupakan zona hambat parsial, yaitu zona hambat yang terbentuk masih terlihat adanya pertumbuhan beberapa koloni bakteri. Rata-rata zona hambat pada Patikan Cina yaitu $0,12 \mathrm{~mm}$, sedangkan pada daun stevia zona hambat yang terbentuk $0,07 \mathrm{~mm}$ dan zona hambat pada daun jambu biji 0,09 mm. Sementara pada uji bakteri S.dysentriae terbentuk zona hambat yang lebih besar dan zona hambat yang terlihat lebih bening. Rata-rata zona hambat yang didapat pada Patikan Cina $10,30 \mathrm{~mm}$, daun Stevia sebesar 1,23 mm sedangkan pada daun jambu biji yaitu $10,29 \mathrm{~mm}$.

\section{Uji Aktivitas Antibakteri Teh Herbal}

Berdasarkan hasil uji daya hambat formula teh herbal terhadap bakteri E.coli dan S.dysentriae dengan metode difusi cakram menunjukkan adanya daya hambat terhadap bakteri yang diuji. Efektivitas formula teh herbal sebagai antibakteri dapat dilihat dengan melakukan pengujian daya hambat menggunakan metode difusi cakram dengan melihat zona bening yang terbentuk di sekitar paper disc yang telah ditetesi $40 \mu \mathrm{l}$ ekstrak teh herbal pada beberapa variasi konsentrasi (70:30:0, $70: 30: 2,5, \quad 70: 30: 5, \quad 70: 30: 7,5, \quad 80: 20: 0$, 80:20:2,5, 80:20:5, 80:20:7,5, 90:10:0, 90:10:2,5, 90:10:5, 90:10:7,5). Paper disc yang telah ditetesi berbagai macam konsentrasi diletakkan di atas permukaan media NA yang dihomogenkan dengan suspensi bakteri S.dysentriae dan E.coli yang telah memadat. Menurut Pratama (2005), zona bening di sekitar paper disc menunjukkan adanya aktivitas antibakteri.

Diameter zona hambat yang diperoleh dari 3 kali pengulangan kemudian dihitung dengan rumus (Diameter vertikal Diameter cakram) + (Diameter horizontalDiameter cakram) / 2 (Susanto, Sudrajat, \& Ruga, 2012) didapatlah hasil pada tabel 2.

Tabel 2. Zona hambat formula teh herbal pada bakteri E.coli dan S. dysentriae

\begin{tabular}{|c|c|c|c|c|c|c|}
\hline \multirow{2}{*}{ Bakteri } & \multirow{2}{*}{$\begin{array}{l}\text { Nama } \\
\text { Sampel }\end{array}$} & \multicolumn{3}{|c|}{ Zona Hambat (mm) } & \multirow{2}{*}{ Rata-rata } & \multirow{2}{*}{$\begin{array}{l}\text { Kontrol Positif } \\
(\mathrm{mm})\end{array}$} \\
\hline & & 1 & 2 & 3 & & \\
\hline \multirow{12}{*}{ E. coli } & P7S3DJ0 & $0,18^{\mathrm{a}}$ & $0,16^{\mathrm{a}}$ & $0,12^{\mathrm{a}}$ & 0,15 & \multirow{4}{*}{10,96} \\
\hline & P7S3DJ2,5 & $1,35^{\mathrm{b}}$ & $1,38^{b}$ & $1,01^{\mathrm{b}}$ & 1,24 & \\
\hline & P7S3DJ5 & $1,42^{b}$ & $1,35^{\mathrm{b}}$ & $1,36^{\mathrm{b}}$ & 1,37 & \\
\hline & P7S3DJ7,5 & $1,31^{\mathrm{b}}$ & $1,42^{\mathrm{b}}$ & $1,34^{\mathrm{b}}$ & 1,35 & \\
\hline & P8S2DJ0 & $0,16^{\mathrm{a}}$ & $0,16^{\mathrm{a}}$ & $0,08^{\mathrm{a}}$ & 0,13 & \multirow{4}{*}{8,59} \\
\hline & P8S2DJ2,5 & $1,41^{\mathrm{b}}$ & $1,73^{b}$ & $1,13^{\mathrm{b}}$ & 1,42 & \\
\hline & P8S2DJ5 & $1,01^{b c}$ & $2,52^{\mathrm{bc}}$ & $1,17^{\mathrm{bc}}$ & 1,5 & \\
\hline & P8S2DJ7,5 & $1,07^{\mathrm{b}}$ & $1,3^{\mathrm{b}}$ & $1,32^{\mathrm{b}}$ & 1,23 & \\
\hline & P9S1DJ0 & $0,08^{\mathrm{a}}$ & $0,07^{\mathrm{a}}$ & $0,08^{\mathrm{a}}$ & 0,55 & \multirow{4}{*}{10,56} \\
\hline & P9S1DJ2,5 & $2,35^{\mathrm{c}}$ & $2,76^{c}$ & $1,83^{\mathrm{c}}$ & 2,31 & \\
\hline & P9S1DJ5 & $1,28^{\mathrm{bc}}$ & $2,81^{\mathrm{bc}}$ & $1,14^{\mathrm{bc}}$ & 1,74 & \\
\hline & P9S1DJ7,5 & $2,79^{c}$ & $2,86^{\mathrm{c}}$ & $1,29^{\mathrm{c}}$ & 2,31 & \\
\hline \multirow{12}{*}{$\begin{array}{l}\text { Shigella } \\
\text { dysentriae }\end{array}$} & P7S3DJ0 & $7,426^{\mathrm{bcd}}$ & $8,88^{\text {bcd }}$ & $8,37^{\mathrm{bcd}}$ & 8,22 & \multirow{4}{*}{10,22} \\
\hline & P7S3DJ2,5 & $4,86^{\mathrm{a}}$ & $2,93^{\mathrm{a}}$ & $4,37^{\mathrm{a}}$ & 4,05 & \\
\hline & P7S3DJ5 & $4,90^{\mathrm{a}}$ & $4,00^{\mathrm{a}}$ & $5,89^{\mathrm{a}}$ & 4,93 & \\
\hline & P7S3DJ7,5 & $3,43^{\mathrm{a}}$ & $4,01^{\mathrm{a}}$ & $5,42^{\mathrm{a}}$ & 4,28 & \\
\hline & P8S2DJ0 & $5,87^{\mathrm{ab}}$ & $4,41^{\mathrm{ab}}$ & $8,41^{\mathrm{ab}}$ & 6,23 & \multirow{4}{*}{20,80} \\
\hline & P8S2DJ2,5 & $10,34^{\mathrm{cd}}$ & $10,31^{\mathrm{cd}}$ & $8,88^{\mathrm{cd}}$ & 9,84 & \\
\hline & P8S2DJ5 & $10,39^{\mathrm{d}}$ & $7,86^{\mathrm{d}}$ & $13,43^{\mathrm{d}}$ & 10,56 & \\
\hline & P8S2DJ7,5 & $8,45^{\mathrm{d}}$ & $13,86^{\mathrm{d}}$ & $10,4^{\mathrm{d}}$ & 10,90 & \\
\hline & P9S1DJ0 & $7,36^{\mathrm{ab}}$ & $6,87^{\mathrm{ab}}$ & $5,83^{\mathrm{ab}}$ & 6,69 & \multirow{4}{*}{12,07} \\
\hline & P9S1DJ2,5 & $6,00^{\mathrm{abc}}$ & $6,44^{\mathrm{abc}}$ & $8,38^{\mathrm{abc}}$ & 6,94 & \\
\hline & P9S1DJ5 & $6,14^{\mathrm{ab}}$ & $6,2^{\mathrm{ab}}$ & $5,94^{\mathrm{ab}}$ & 6,09 & \\
\hline & P9S1DJ7,5 & $4,66^{\mathrm{ab}}$ & $4,66^{\mathrm{ab}}$ & $9,4^{\mathrm{ab}}$ & 6,24 & \\
\hline
\end{tabular}

Keterangan: Angka yang diberi huruf yang berbeda menunjukkan pengaruh yang berbeda nyata 
Mekanisme penghambatan terhadap pertumbuhan bakteri dapat berupa kerusakan dinding sel yang mengakibatkan lisis atau penghambatan sintesis dinding sel, pengubahan permeabilitas membran sitoplasma sehingga menyebabkan keluarnya bahan makanan melalui dinding sel, denaturasi protein sel dan perusakan sistem metabolisme di dalam sel dengan cara penghambatan kerja enzim intraseluler (Pelczar dan Reid, 1972).

Adanya zona bening di sekitar paper disc yang menandakan bahwa formula teh herbal tersebut dapat menghambat bakteri E.coli. Pada hasil pengukuran zona hambat pada tabel 2 menunjukkan untuk uji daya hambat teh herbal dengan berbagai macam konsentrasi memiliki nilai daya hambat berkisar antara 1,01-2,52 mm, maka aktivitas penghambatan bakteri E.coli dikategorikan lemah karena, menurut Davis \& Stout (1971) menyatakan bahwa apabila zona hambat yang terbentuk pada uji difusi agar berukuran kurang dari 5 $\mathrm{mm}$, maka aktivitas penghambatannya dikategorikan lemah. Apabila zona hambat berukuran 5-10 mm dikategorikan sedang, 10-19 mm dikategorikan kuat dan $20 \mathrm{~mm}$ atau lebih dikategorikan sangat kuat. Berdasarkan zona daya hambat yang didapat dapat disimpulkan bahwa aktivitas antibakteri E.coli secara keseluruhan formula teh herbal yang didapat bersinergis satu dengan yang lain, karena zona hambat yang didapat pada produk lebih besar dari zona hambat yang didapat pada bahan baku.

Secara statistik terlihat bahwa masing-masing perlakuan formula ekstrak teh herbal memiliki perbedaan yang signifikan ditunjukkan dengan nilai $\mathrm{F}$ hitung $(7,83)>\mathrm{F}$ tabel $(2,21) \mathrm{P}(\mathrm{sig})<$ 0,05 , yang berarti bahwa rata-rata zona hambat bakteri E.coli dari setiap perlakuan formula teh herbal tersebut berbeda nyata satu sama lain.

Berbeda dengan bakteri E.coli. pada bakteri S.dysentriae mempunyai daya hambat yang cukup besar dan mempunyai zona bening yang lebih jelas . Berdasarkan tabel 2, zona hambat untuk bakteri S.dysentriae antara $4,05-10,90 \mathrm{~mm}$ yaitu zona hambat terkecil dimiliki formula teh herbal P7S3DJ2,5 sedangkan zona hambat terbesar yakni teh herbal dengan formula P8S3DJ7,5. Maka aktivitas penghambat bakteri Shigella dikategorikan sedang. Dapat disimpulkan untuk aktivitas antibakteri S.dysentriae hanya beberapa formula teh herbal yang bersinergis. Karena beberapa formula teh herbal memiliki zona hambat yang lebih kecil dibandingkan zona hambat bahan baku.

Secara statistika pada masing-masing perlakuan formula teh herbal menunjukkan perbedaan yang signifikan dengan nilai $\mathrm{F}$ hitung $(5,88)>$ F tabel $(2,21)$ dan $\mathrm{P}($ sig $)<$ 0,005 , dengan kata lain rata-rata zona hambat bakteri S.dysentriae dari setiap perlakuan formula teh herbal berbeda nyata satu sama lain.

\section{Analisis fisikokimia (kadar air, kadar abu, kadar tanin dan uji fitokimia) bahan baku teh herbal}

Kadar air merupakan perbandingan antara jumlah air dalam bahan dengan berat bahan keringnya. Kadar air yang terkandung di dalam bahan sangat mempengaruhi kualitas, nilai dan kesegaran bahan tersebut, kadar air yang tinggi mengakibatkan mudahnya bakteri, kapang, dan khamir untuk berkembang biak, sehingga akan terjadi perubahan pada bahan pangan (Barbosa \& Vega, 1996). Tujuan analisis ini adalah memberikan batasan minimal rentang besarnya kandungan air di dalam serbuk simplisia tersebut. Persentase kadar air pada bahan baku yang digunakan dapat dilihat pada tabel 3 .

Tabel 3. Hasil analisis fisikokimia bahan baku

\begin{tabular}{lccr}
\hline \multirow{2}{*}{ Bahan baku } & \multicolumn{3}{c}{ Analisis } \\
\cline { 2 - 4 } & $\begin{array}{c}\text { Kadar } \\
\text { Air }\end{array}$ & $\begin{array}{c}\text { Kadar } \\
\text { Abu }\end{array}$ & Kadar Tanin \\
\hline Patikan Cina & $10,74 \%$ & $1,72 \%$ & $990,94 \mathrm{ppm}$ \\
Daun Jambu Biji & $12,95 \%$ & $2,69 \%$ & $624 \mathrm{ppm}$ \\
Daun Stevia & $9,76 \%$ & $10,48 \%$ & $1154,14 \mathrm{ppm}$ \\
SNI & $10 \%$ & $8 \%$ & positif \\
\hline
\end{tabular}

Persyaratan kadar air simplisia menurut parameter standar yang berlaku adalah tidak 
lebih dari $10 \%$ (Fardiaz, Andarwulan, Wijaya \& Puspitasari, 1992). Hasil penetapan kadar air untuk simplisia daun stevia yaitu $9,76 \%$. Hal ini berati simplisia daun stevia memenuhi persyaratan kadar air. Sedangkan persentase kadar air untuk patikan cina dan daun jambu biji melebihi standar mutu simplisia kering yaitu 10,74 $\%$ dan $12,95 \%$, hal ini dikarenakan kadar air yang terhitung pada simplisia kering merupakan air terikat. Menurut Sebanek (1992), air terikat tidak bisa menguap dari jaringan pada proses pengeringan dengan tekanan uap rendah. Oleh karena itu, tidak semua air yang ada di dalam daun bisa diuapkan. $\mathrm{Abu}$ adalah komponen anorganik yang merupakan sisa pembakaran bahan organik.

Kadar abu dihitung dari pengurangan berat yang terjadi selama pembakaran sempurna dari bahan-bahan organik pada suhu tinggi (biasanya $500^{\circ}-$ $\left.600^{\circ} \mathrm{C}\right)$. Pengurangan berat ini terjadi karena penguapan senyawa -senyawa organik.

Penetapan kadar abu dilakukan untuk mengetahui kandungan mineral yang terkandung di dalam simplisia. Menurut Gaman dan Sherrington (1992), unsur mineral adalah unsur yang diperlukan tubuh dalam jumlah yang relatif kecil, tetapi keberadaannya tetap diperlukan sebagai zat pembangun dan pengatur.

Berdasarkan hasil pengujian, kadar abu dari daun jambu biji dan patikan cina yang dihasilkan memiliki nilai 2,69\% dan 1,72\%, sedangkan kadar abu untuk daun stevia yaitu 10,48. Nilai kadar abu ini memenuhi standar mutu simplisia kering SNI, yaitu tidak boleh lebih dari $8 \%$, namun kadar abu untuk daun stevia tidak memenuhi standar mutu. Tanin merupakan salah satu jenis senyawa kimia yang termasuk ke dalam golongan polifenol yang terdapat pada tumbuhan. Kandungan tanin dalam teh dapat digunakan sebagai pedoman mutu, karena tanin juga memberikan kemantapan rasa. (Winarno, 1997 ).

Berdasarkan hasil pengujian, bahan baku yang telah disiapkan dilarutkan dengan akuades kemudian ditambahkan $\mathrm{FeCl}_{3}$ menghasilkan warna biru kehitaman terbukti bahwa pada bahan baku mengandung tanin yang tergolong tanin terhidrolisis, dimana dengan adanya gugus fenol pada tanin yang akan berikatan dengan $\mathrm{FeCl}_{3}$ membentuk kompleks berwarna biru.

Uji fitokimia dilakukan untuk mengidentifikasi keberadaan senyawa berdasarkan golongannya sebagai informasi awal kandungan senyawa yang terdapat pada masing-masing bahan baku. Hasil uji yang diperoleh dapat dilihat pada Tabel 4.

Tabel 4. Hasil uji fitokimia bahan baku

\begin{tabular}{llccc}
\hline \multirow{2}{*}{$\begin{array}{l}\text { Senyawa Metabolit } \\
\text { Sekunder }\end{array}$} & Metode Pengujian & \multicolumn{2}{c}{ Hasil } \\
\cline { 2 - 5 } & Pereaksi meyer & $\begin{array}{c}\text { Patikan } \\
\text { Cina }\end{array}$ & $\begin{array}{c}\text { Daun } \\
\text { Stevia }\end{array}$ & $\begin{array}{c}\text { Daun Jambu } \\
\text { Biji }\end{array}$ \\
\hline Alkaloid & Pereaksi dragendrof & - & + & - \\
& Pereaksi Bouchardat & + & + & + \\
Flavonoid & HCl pekat \& serbuk Mg & + & + & + \\
& NaOH 10\% & + & + & + \\
Tanin & Air \& FeCl & + & + & + \\
Saponin & Air panas & - & & + \\
Steroid & Uji Lieberman Burchard & + & & + \\
Triterpen & Uji Lieberman Burchard & - & & + \\
\hline
\end{tabular}

Keterangan: $\quad+=$ mengandung senyawa metabolit sekunder - = tidak mengandung senyawa metabolit sekunder 


\section{Analisis Kadar Sari dan Nilai pH Formula Teh Herbal}

\section{Kadar Sari}

Kadar sari digunakan untuk mengetahui jumlah partikel yang dapat larut di dalam air panas. Semakin banyak partikel yang larut maka kadar sari yang dihasilkan semakin tinggi pula (Gaman \& Sherrington, 1992). Kadar sari yang dapat diekstrak dengan air diperkirakan berasal dari golongan tanin karena menurut Voigt (1994), senyawa dalam golongan tersebut merupakan senyawa yang dapat larut dalam air. Cairan hasil ekstraksi sangat dipengaruhi oleh jenis dan komposisi cairan pengekstraknya. Air sebagai pelarut polar dapat mengekstrak jenis gula-gulaan, bahan berlendir, amina, tanin, vitamin, asam organik, asam anorganik, dan garam anorganik dengan baik. Uji kadar sari dilakukan dengan cara menguapkan filtrat formula teh herbal yang telah dibuat di atas penangas air, kemudian dikeringkan kembali di dalam oven. Berdasarkan hasil skrining fitokimia yang dilakukan, secara keseluruhan formula teh herbal memiliki senyawa metabolit sekunder seperti alkaloid, flavanoid, tanin, dan saponin.

\section{DAFTAR RUJUKAN}

Afrida, Jhon, N., Dwilistiani, D., \& Nengsih, H. (2014). Isolasi senyawa metabolit sekunder dari ekstrak nHeksan tumbuhan patikan cina (Euphorbia thymifolia Linn.). Jurnal of The Indonesian Society of Integrated Chemistry, 6(1), 9-12.

Barbosa-Canovas, G. V. \& Vega-Mercado, H. (1996). Dehydration of foods. New York: Chapman and Hall.

Baslas, R.K., Agarwal, R. (1980). Chemical investigation of some anticancer plants of Euphorbia genus. Indian Jurnal Chemistry, 19B(8), 71-78.

\section{KESIMPULAN}

Hasil penelitian menunjukkan bahwa teh herbal patikan cina dengan penambahan daun stevia dan daun jambu biji memberikan pengaruh berbeda terhadap nilai $\mathrm{pH}$, kadar sari, sifat organoleptik (aroma, warna, dan rasa) serta mampu menghambat pertumbuhan bakteri E.coli dan S.dysentriae. Berdasarkan hasil pembobotan secara subyektif maka diperoleh teh herbal dengan formula P7S3DJ0 yaitu dengan campuran patikan cina $70 \%$;stevia $30 \%$; tanpa penambahan daun jambu biji sebagai produk terbaik. Produk teh herbal terbaik yang terpilih memiliki $\mathrm{pH} 5,02$; kadar sari $0,5 \%$; serta mampu menghambat E.coli 0,15 mm dan S.dysentriae 8,22 mm.

\section{UCAPAN TERIMA KASIH}

Terimakasih kepada Lembaga Penelitian dan Pengabdian Masyarakat Universitas Jambi yang telah membiayai penelitian ini melalui DIPA PNBP LPPM Universitas Jambi Tahun 2017.

Davis, W. W. \& Stout, T. R. (1971). Disc plate method of microbiological antibiotic assay. Applied Microbiology. 22(4),659-665.

Dwilistiani, D., (2013), Isolasi dan karakterisasi senyawa steroid pada tumbuhan patikan cina (Euphorbia thymifolia Linn.). (Skripsi), Universitas Jambi. Jambi.

Fardiaz, D., Andarwulan, N., Wijaya, C.H., \& Puspitasari, N.L. (1992). Teknik analisis sifat kimia dan fungsional komponen pangan. Bogor: PAU Pangan dan Gizi, IPB. 
Gaman, P. M. \& K. B. Sherrington. (1992). Ilmu pangan: Pengantar ilmu pangan nutrisi dan mikrobiologi. Yogyakarta: Gajah Mada Universitas Press,.

Pelczar, M.J., \& Reid, R.D. (1972). Microbiology. New York: Mc Graw Hill Book Company.

Pratama, M.R. (2005). Pengaruh ekstrak serbuk kayu siwak (Salvadora persica) terhadap pertumbuhan bakteri streptococcus mutans dan staphylococcus aureus dengan metode difusi agar. (Skripsi). Institut Teknologi Sepuluh Nopember. Solo.

Sebanek, J. (1992). Structural integrity and organization of plants. The principle of integrity. Plant physiology. 12(1).
Susanto, Sudrajat, D., \& Ruga, R. (2012). Studi kandungan bahan aktif tumbuhan meranti merah (Shorea leprosula Miq) sebagai sumber senyawa antibakteri. Mulawarmnan Scientific. 11(2), 181-90.

Sushma, K., \& Singh, R. (2016). Flavan-3ol isomers isolated from Euphorbia thymifolia Linn. Pharmacogn. Commn. 6(1), 28-33.

Utami, P. (2008). Buku pintar tanaman obat. Jakarta: Agromedia Pustaka.

Voigt, R. (1994). Buku pelajaran teknologi farmasi. (Terjemahan). Yogyakarta: Gajah Mada University Press.

Winarno, F. G. (1997). Kimia pangan dan gizi. Jakarta: Gramedia. 